\title{
Effects of nitrogen application rate and a nitrification inhibitor dicyandiamide on methanotroph abundance and methane uptake in a grazed pasture soil
}

\author{
Yu Dai • Hong J. Di • Keith C. Cameron • Ji-Zheng He
}

Received: 27 April 2013 / Accepted: 13 May 2013 /Published online: 29 May 2013

(C) Springer-Verlag Berlin Heidelberg 2013

\begin{abstract}
Methane-oxidizing bacteria (methanotrophs) in the soil are a unique group of methylotrophic bacteria that utilize methane $\left(\mathrm{CH}_{4}\right)$ as their sole source of carbon and energy which limit the flux of methane to the atmosphere from soils and consume atmospheric methane. A field experiment was conducted to determine the effect of nitrogen application rates and the nitrification inhibitor dicyandiamide (DCD) on the abundance of methanotrophs and on methane flux in a grazed pasture soil. Nitrogen $(\mathrm{N})$ was applied at four different rates, with urea applied at 50 and $100 \mathrm{~kg} \mathrm{~N}$ ha $^{-1}$ and animal urine at 300 and $600 \mathrm{~kg} \mathrm{~N} \mathrm{ha}^{-1}$. DCD was applied at $10 \mathrm{~kg} \mathrm{ha}^{-1}$. The results showed that both the DNA and selected mRNA copy numbers of the methanotroph $p m o A$ gene were not affected by the application of urea, urine or DCD. The methanotroph DNA and mRNA pmoA gene copy numbers were low in this soil, below $7.13 \times 10^{3} \mathrm{~g}^{-1}$ soil and $3.75 \times 10^{3} \mu^{-1} \mathrm{RNA}$, respectively. Daily $\mathrm{CH}_{4}$ flux varied slightly among different treatments
\end{abstract}

Responsible editor: Zhihong Xu

Y. Dai · J.-Z. He $(\bowtie)$

State Key Laboratory of Urban and Regional Ecology, Research

Center for Eco-Environmental Sciences, Chinese Academy

of Sciences, Beijing 100085, China

e-mail: jzhe@rcees.ac.cn

Y. Dai

University of Chinese Academy of Sciences, Beijing 100049,

China

H. J. Di $(\bowtie) \cdot$ K. C. Cameron

Centre for Soil and Environmental Research, Lincoln University, Lincoln, 7674PO Box 85084, Christchurch, New Zealand

e-mail: Hong.Di@lincoln.ac.nz

J.-Z. He

Environmental Futures Centre, School of Biomolecular and Physical Sciences, Griffith University, Nathan, Brisbane, QLD 4111, Australia during the experimental period, ranging from $-12.89 \mathrm{~g} \mathrm{CH}_{4}$ ha $^{-1}$ day $^{-1}$ to $-0.83 \mathrm{~g} \mathrm{CH}_{4} \mathrm{ha}^{-1}$ day $^{-1}$, but no significant treatment effect was found. This study suggests that the application of urea fertilizer, animal urine returns and the use of the nitrification inhibitor DCD do not significantly affect soil methanotroph abundance or daily $\mathrm{CH}_{4}$ fluxes in grazed grassland soils.

Keywords Nitrogen application rate · Dicyandiamide (DCD) - Methane-oxidizing bacteria $\cdot$ Methane flux . Methanotroph DNA and mRNA · Field experiment

\section{Introduction}

Methane $\left(\mathrm{CH}_{4}\right)$ is the most abundant non- $\mathrm{CO}_{2}$ greenhouse gas in the atmosphere today (currently about 1.8 parts per million as mole fraction in dry air), and it is about 25 times more efficient at absorbing infrared radiation than $\mathrm{CO}_{2}$ (IPCC 2007). With increasing concern about the future impacts of global climate change, intensified research efforts regarding variability in sources and sinks of atmospheric methane are essential to mitigating its environmental impact. Pasture soils are both sources and sinks of atmospheric methane. The habitats of ruminants that contain methanogenic archaea in their guts are bred and expanded in the grassland (Külling et al. 2002). However, most of the methane produced from grasslands is removed by the activity of methane-oxidizing bacteria (MOB; Conrad 2009). On balance, upland soils (e.g. forests, grasslands, meadows, savannah and desert) are the most efficient sinks of atmospheric methane, oxidizing methane by as yet unknown microorganisms using high affinity enzyme systems (Kolb 2009).

Based on their cell morphology, phylogeny and metabolic pathways, MOB can be divided into two major groups, type I and type II, belonging to the families Methylococcaceae ( $\gamma$-proteobacteria), and Methylocystaceae and Bejerinckiaceae 
( $\alpha$-proteobacteria), respectively (Hanson and Hanson 1996; Dedysh 2009). The key enzymes responsible for methane oxidation of MOB are methane monooxygenases (MMOs), and almost all of the cultivated MOB possess a membrane-bound particulate form MMO. Only the genera Methylocella and Methyloferula lack this enzyme and instead have a soluble MMO (Dedysh 2009; Vorobev et al. 2011). The pmoA gene is an excellent functional gene marker for studying MOB in various environments (Costello and Lidstrom 1999; Kolb et al. 2003; Zheng et al. 2008, 2013) as its phylogeny matches that of the $16 \mathrm{~S}$ rRNA gene very well (Kolb et al. 2003).

In grazed grassland, as animals graze outdoor pastures, the majority of the nitrogen $(\mathrm{N})$ ingested by animals goes back to the soil in excreta, particularly in the urine (Di and Cameron 2002). Most of the $\mathrm{N}$ in the animal urine is urea whose loading rate can be up to $1,000 \mathrm{~kg} \mathrm{~N} \mathrm{ha}^{-1}$. A large proportion of the surplus $\mathrm{N}$ could be lost through leaching as nitrate $\left(\mathrm{NO}_{3}{ }^{-}\right)$or emitted as nitrous oxide $\left(\mathrm{N}_{2} \mathrm{O}\right)$ in the urine patches of grazed pastures, causing adverse economic and environmental impacts (Di and Cameron 2005; Di et al. 2007). It has been shown that after the application of $\mathrm{N}$ fertilizer to grazed pasture soil, the abundance and activity of ammonia-oxidizing bacteria (AOB) increased significantly, leading to significantly increased nitrification rates (Di et al. 2009; Shen et al. 2011; Zhang et al. 2012). Recently, a nitrification inhibitor dicyandiamide (DCD) is used as an effective mitigation tool to control $\mathrm{N}$ losses from the urine patches by inhibiting the nitrification process. It has been shown that DCD could significantly inhibit the $\mathrm{AOB}$ growth and activity, thus significantly reducing $\mathrm{NO}_{3}{ }^{-}$leaching and $\mathrm{N}_{2} \mathrm{O}$ emissions in grazed pastures (Di and Cameron 2005; Di et al. 2007, 2009, 2010; He et al. 2012; Zhang et al. 2012).

The question arises whether and how the MOB populations are influenced by the deposition of animal urine and application of DCD in grazed pastures as the pmoA and amo $A$ genes are evolutionarily related and share similar substrates (Holmes et al. 1995). In previous studies, inhibition (Steudler et al. 1989; Bosse et al. 1993; Zheng et al. 2013), stimulation (Bodelier et al. 2000; Krüger and Frenzel 2003) or no effect (Delgado and Mosier 1996; Bodelier and Laanbroek 2004) of ammonium-based $\mathrm{N}$ fertilization on aerobic MOB were observed. In grazed pasture soils, Di et al. (2011) found that the abundance of MOB is not affected by urine deposition or the application of DCD. However, the study was based on a laboratory incubation, and there is a lack of a similar study under field conditions where the soil conditions are more variable with regard to moisture and temperature. Therefore, more research is required, particularly under field conditions, to improve our understanding of possible impacts on MOB population dynamics and $\mathrm{CH}_{4}$ uptakes by the applications of $\mathrm{N}$ fertilizer, animal urine $\mathrm{N}$ returns and the application of DCD in grazed grassland.

Therefore, a field study was conducted to determine the effect of different rates of $\mathrm{N}$ inputs and DCD on the

population dynamics of ammonia oxidizers and MOB in a grassland soil. The results on ammonia oxidizers and nitrous oxide emissions have been reported previously (Dai et al. 2012). This paper reports the dynamics of MOB and methane flux as affected by different rates of $\mathrm{N}$ and the nitrification inhibitor DCD.

\section{Materials and methods}

Site description

A field experiment was conducted on the Lincoln University Research Dairy Farm, $15 \mathrm{~km} \mathrm{SW}$ of Christchurch $\left(43^{\circ} 38^{\prime}\right.$ $11^{\prime \prime} \mathrm{S} ; 172^{\circ} 26^{\prime} 18^{\prime \prime} \mathrm{E}$ ), New Zealand, from May 2011 to August 2011. The soil type at the trial site is a freedraining Templeton Silt Loam (Hewitt and Whenua 1998) or an Udic Haplustepts (Staff 1998). The pasture on the farm was a mixture of perennial ryegrass (Lolium perenne $\mathrm{cv}$. 'Bronsyn' and 'Impact') and white clover (Trifolium repens cv. 'Aran' and 'Sustain'). Soil chemical properties at the trial site are presented in Table 1.

\section{Experimental design and treatment application}

The experimental area was separated into 32 plots. Gas rings (50 $\mathrm{cm}$ diameter) were inserted into the field to a depth of $15 \mathrm{~cm}$. These plots were used for gas sampling after the application of the treatments. Separate rings $(50 \mathrm{~cm}$ diameter $)$ inserted into the soil next to the gas rings received the same treatments as the gas rings, and were used for soil sampling and soil analysis.

Eight treatments (Table 2) were replicated four times and randomly assigned to the plots. The $\mathrm{N}$ sources were applied at a wide range of rates to test if methanotrophs would be affected by different $\mathrm{N}$ environments. The animal urine $\mathrm{N}$ rates of 300 and $600 \mathrm{~kg} \mathrm{~N} \mathrm{ha}^{-1}$ were to simulate those from a sheep and a cattle urine deposition in grazed pastures, respectively. DCD was

Table 1 Chemical properties of the soil used

${ }^{\mathrm{a}} \mathrm{pH}$ was measured at 1:2.5 air-dried soil/water ratio

\begin{tabular}{ll}
\hline $\mathrm{pH}^{\mathrm{a}}$ & 5.8 \\
Total P & $0.71 \mathrm{~g} \mathrm{~kg}^{-1}$ \\
Total N & $3.0 \mathrm{~g} \mathrm{~kg}^{-1}$ \\
Total S & $0.35 \mathrm{~g} \mathrm{~kg}^{-1}$ \\
Olsen P & $43 \mathrm{mg} \mathrm{kg}^{-1}$ \\
Sulphate S & $30 \mathrm{mg} \mathrm{kg}^{-1}$ \\
$\mathrm{CEC}$ & $15 \mathrm{cmol}_{\mathrm{c}} \mathrm{kg}^{-1}$ \\
Exchangeable Ca & $7.9 \mathrm{cmol}_{\mathrm{c}} \mathrm{kg}^{-1}$ \\
Exchangeable $\mathrm{Mg}$ & $0.58 \mathrm{cmol}_{\mathrm{c}} \mathrm{kg}^{-1}$ \\
Exchangeable $\mathrm{K}$ & $0.45 \mathrm{cmol}_{\mathrm{c}} \mathrm{kg}^{-1}$ \\
Exchangeable $\mathrm{Na}$ & $0.20 \mathrm{cmol}_{\mathrm{c}} \mathrm{kg}^{-1}$ \\
Base saturation & $62 \%$ \\
\hline
\end{tabular}


applied to test if the MOB growth would be influenced by this nitrification inhibitor (Di et al. 2011).

The soil was wet to field capacity before the application of the treatments. Urea was dissolved in water and applied in a 2-L solution to the plots. Fresh animal urine was collected from Friesian cows, analysed for total N concentration, diluted to $6 \mathrm{~g} \mathrm{~N} \mathrm{~L}^{-1}$ and applied in a 2-L solution to the plots on the same day. Two liters of water was also applied to controls to keep the water addition consistent in all the treatments. DCD was applied in $15 \mathrm{~mL}$ solution at the rate of $10 \mathrm{~kg} \mathrm{ha}^{-1}$ on the same day, once the urea or urine had been applied (Di and Cameron 2006). The 15-mL DCD solution was applied to the plots evenly with a watering can.

Monitoring of soil water and temperature

Soil temperature was recorded by using an automated LM35CZ temperature sensor (National Semiconductor, Tokyo, Japan) at the 50-mm depth. Rainfall was recorded by a tipping bucket rain gauge installed at the farm site.

\section{Quantification of MOB pmoA gene by real-time PCR assays}

Soil samples were taken 1 day (12 May 2011) and then 13 (24 May 2011), 27 (07 June 2011), 55 (05 July 2011) and 83 (02 August 2011) days after the application of the treatments. For each plot, three cores (3 $\mathrm{cm}$ diameter, $0-10 \mathrm{~cm}$ depth) were collected and bulked into a single sample. The samples were uniformly mixed through a 5-mm sieve immediately after sampling and were stored in a freezer at $-80{ }^{\circ} \mathrm{C}$ before DNA extraction. The soil $(0.4 \mathrm{~g})$ was then extracted for nucleic acid using MoBio Powersoil ${ }^{\mathrm{TM}}$ DNA Isolation Kits (San Diego, CA) according to the manufacturer's instructions. DNA was eluted with $100 \mathrm{~mL}$ of solution C6 (MoBio Laboratories, CAT. No. 12888-100) and stored at $-80^{\circ} \mathrm{C}$ before being analysed.

Table 2 Experimental treatments used in the field plot study

\begin{tabular}{|c|c|c|}
\hline Number & Treatment & Abbreviation \\
\hline 1 & Control $^{\mathrm{a}}$ & $\mathrm{CK}$ \\
\hline 2 & Urea-N ${ }^{b} 50$ & N50 \\
\hline 3 & Urea-N 100 & N100 \\
\hline 4 & Urine-N 300 & N300 \\
\hline 5 & Urine-N 600 & N600 \\
\hline 6 & Urea-N $50+{ }^{\mathrm{c}} \mathrm{DCD}$ & $\mathrm{N} 50+\mathrm{DCD}$ \\
\hline 7 & Urine-N $300+\mathrm{DCD}$ & $\mathrm{N} 300+\mathrm{DCD}$ \\
\hline 8 & Urine-N $600+\mathrm{DCD}$ & $\mathrm{N} 600+\mathrm{DCD}$ \\
\hline
\end{tabular}

${ }^{\mathrm{a}}$ Control: No nitrogen fertilizer or DCD

${ }^{\mathrm{b}} 50$ : the unit of 50 is $\mathrm{kg} \mathrm{ha}^{-1}$

${ }^{\mathrm{c}}$ DCD: the concentration of DCD is $10 \mathrm{~kg} \mathrm{ha}^{-1}$
Transcription of the MOB $p m o A$ gene was studied by determining the mRNA copy numbers in the soil samples collected on day 27 (07 June 2011). The mRNA in $1 \mathrm{~g}$ of fresh soil was extracted using the MoBio RNA Power SoilTM Total RNA Isolation Kit, following the manufacturer's instructions. Other soil samples were not extracted and analysed for RNA due to resource constraints. To generate cDNA, the extracted mRNA was treated using the Turbo DNA-free Kit (ABI) to remove the DNA. cDNA was produced using Superscript III reverse transcriptase (Invitrogen NZ, Auckland). Random primers (Invitrogen NZ) were used at a concentration of $2.5 \mathrm{nmol}$ per reaction. Two negative controls were performed with all reactions. The first control contained soil RNA template and all DNAse/RT reagents, except for the final addition of the RT enzyme. A second control contained no template (water only) to ensure that all reagents were free from possible contaminants.

All the soil DNA and RNA samples were analysed for the abundance of methanotrophs with primers targeting the MOB pmoA gene using real-time PCR (Holmes et al. 1995; Costello and Lidstrom 1999; Zheng et al. 2008; Di et al. 2011). All the PCRs were set up using the CAS-1200 Robotic liquid handling system (Corbett Life Science, Australia), and real-time PCR was performed on a Rotor-Gene ${ }^{\mathrm{TM}} 6000$ (Corbett Life Science). Possible inhibition of the real-time PCR was assessed by running a series of tenfold dilutions of the extracted DNA and determining the amplification efficiency of each diluted sample. Inhibition was observed without dilution, but high amplification efficiencies of 92-99\% were obtained for the methanotroph quantification after a tenfold dilution. A tenfold dilution of each soil DNA sample was thus used for the final analysis. However, no dilution was needed for the soil RNA samples which were directly used. The pmoA gene was quantified using the primer pair A189 (5'-GGNGACTGGGACTTCTGG-3') and Mb661 (5'-CCGGMGCAACGTCYTTACC-3') (Costello and Lidstrom 1999) with SYBRs Premix Ex TaqTM (TaKaRa, Japan) using the thermal profiles as described in $\mathrm{Di}$ et al. (2011). The $20-\mu \mathrm{L}$ reaction mixture consisted of $10.0 \mu \mathrm{L}$ of SYBRs Premix Ex Taq ${ }^{\mathrm{TM}}$, plus primers and $1.5 \mu \mathrm{L}$ of template DNA. A melting curve analysis was performed to confirm PCR product specificity after amplification by measuring fluorescence continuously as the temperature increased from 50 to $99{ }^{\circ} \mathrm{C}$. Data analysis was carried out using RotorGene $^{\mathrm{TM}} 6000$ series software 1.7.

Standard curves for real-time PCR were developed as follows: briefly a $p m o A$ gene fragment (verified by DNA sequencing) was purified (PCR clean up kit; Axygen, USA) and cloned into the pGEM-T Easy Vector (Promega, Madison, WI, USA). The resulting ligation mix was transformed into Escherichia coli JM109 competent cells (Promega, Madison, WI, USA) following the manufacturer's instructions and plasmids used as standards for 
quantitative analyses. The plasmid DNA concentration was determined on a Qubit ${ }^{\mathrm{TM}}$ fluorometer (Invitrogen, Auckland, New Zealand), and the copy numbers of targeted genes were calculated directly from the concentration of the extracted plasmid DNA. Tenfold serial dilutions of a known copy number of the plasmid DNA were subjected to a real-time PCR assay in triplicate to generate an external standard curve and to check the amplification efficiency. High efficiencies of 95-98\% were obtained in pmo $A$ gene amplification, with the $R$ value ranging between 0.996 and 0.998 .

Soil extractable $\mathrm{NH}_{4}{ }^{+}$concentrations

Soil samples were taken five times in a same manner as that above during the experimental period and extracted with $2 \mathrm{M} \mathrm{KCl}$ to determine the $\mathrm{NH}_{4}{ }^{+}-\mathrm{N}$ concentrations on a flow injection analyser (Tecator Inc., Sweden).

$\mathrm{CH}_{4}$ sampling and analysis

$\mathrm{CH}_{4}$ flux was determined using a standard closed chamber method following Hutchinson and Mosier (1981). The gas chamber was made of a metal cylinder, insulated on the outside with a 2-cm-thick polystyrene foam to avoid heating of the atmosphere in the chamber during sampling. The chamber was fitted inside a small water through which was mounted around the top of each plot for gas sampling. At each sampling time, the chamber was placed on top of the plots for a total of $40 \mathrm{~min}$, and then three $12-\mathrm{mL}$ samples were taken 20 min apart, using a syringe through a rubber septum fitted on top of the gas collection chamber. Gas samples were collected twice per week in first month and then once per week for the next 2 months. The three samples collected with 20-min interval allowed the calculation of $\mathrm{CH}_{4}$ flux in the enclosure during the sampling period. Each sampling was carried out during the middle of the day between 1-2 p.m. when $\mathrm{CH}_{4}$ flux was similar to the daily means (Di et al. 2007). Methane was analysed using gas chromatography (SRI 8610 gas chromatograph, SRI Instruments, CA, USA) equipped with a flame ionization detector.

Data analysis for $\mathrm{CH}_{4}$ flux

Hourly $\mathrm{CH}_{4}$ uptake rates were calculated based on the decrease of $\mathrm{CH}_{4}$ in the samples collected assuming first-order kinetics (Mosier et al. 1991) rather than linear decay as had been suggested (Steudler et al. 1989). Daily uptake rates were then calculated based on the hourly fluxes, assuming that the fluxes measured represented the average hourly flux of the day (Di and Cameron 2006). Cumulative uptakes were calculated by integrating the measured daily fluxes for the whole experiment. Statistical analysis of the data was performed using SPSS 17.0 (Statistical Product and Service Solutions,
SPSS Inc., USA), and the graphs were created in Microsoft Excel 2007 (Microsoft Corporation, USA).

\section{Results}

Soil temperature and water inputs

The 50-mm soil daily average temperature varied from 2.2 to $13.1{ }^{\circ} \mathrm{C}$ during the experimental period (Fig. 1a).Total water inputs, including irrigation and rainfall, reached about $120 \mathrm{~mm}$ during the period (Fig. 1b).

Methanotroph abundance

The methanotroph $p m o A$ gene copy numbers were low in all treatments throughout the experimental period which ranged from $1.01 \times 10^{3}$ to $7.13 \times 10^{3} \mathrm{~g}^{-1}$ soil. There were no significant differences in the methanotroph $p m o A$ gene copy numbers among all treatments during the sampling period (Fig. 2, $P>$ 0.05). Therefore, application of $\mathrm{N}$ at the different rates and DCD had no significant effect on methanotroph abundance in this experiment (Fig. 2, $P>0.05$ ). Similarly, no significant difference was found in the mRNA copy numbers of methanotroph $p m o A$ gene among the different treatments at the date of June 7 (Fig. 3, $P>0.05$ ). The MOB mRNA pmoA gene copy numbers, ranging from $1.07 \times 10^{3}$ to $3.75 \times 10^{3}$ per microgram of RNA, were positively related to the daily average $\mathrm{CH}_{4}$ uptake rates at the date of June 7 (Fig. 4). The following significant exponential relationship was found between the daily average $\mathrm{CH}_{4}$ uptake rates and the methanotroph mRNA pmoA gene copy numbers (Fig. 4):

$y=3.2304 \mathrm{e}^{0.1905 x}$

$R^{2}=0.7467 ; P<0.01$

Where $y$ is the daily average $\mathrm{CH}_{4}$ uptake rates (in grams of $\mathrm{CH}_{4}$ per hectare per day) and $x$ is the methanotroph mRNA pmoA gene copy numbers (in thousand copies per microgram of RNA).

Soil extractable $\mathrm{NH}_{4}{ }^{+}$concentrations

Soil $\mathrm{NH}_{4}{ }^{+}-\mathrm{N}$ concentrations were strongly influenced by the application of nitrogen and DCD. During the first month of experiment, the soil $\mathrm{NH}_{4}{ }^{+}-\mathrm{N}$ concentrations of the $\mathrm{N} 600$ treatment were significantly higher than those of the other treatments without DCD (Fig. 5a, $P<0.05$ ). The soil $\mathrm{NH}_{4}{ }^{+}-\mathrm{N}$ concentrations of the N300 treatment were also significantly 
Fig. 1 Daily average soil temperature at 50-mm depth (a) and daily and cumulative water inputs (b)
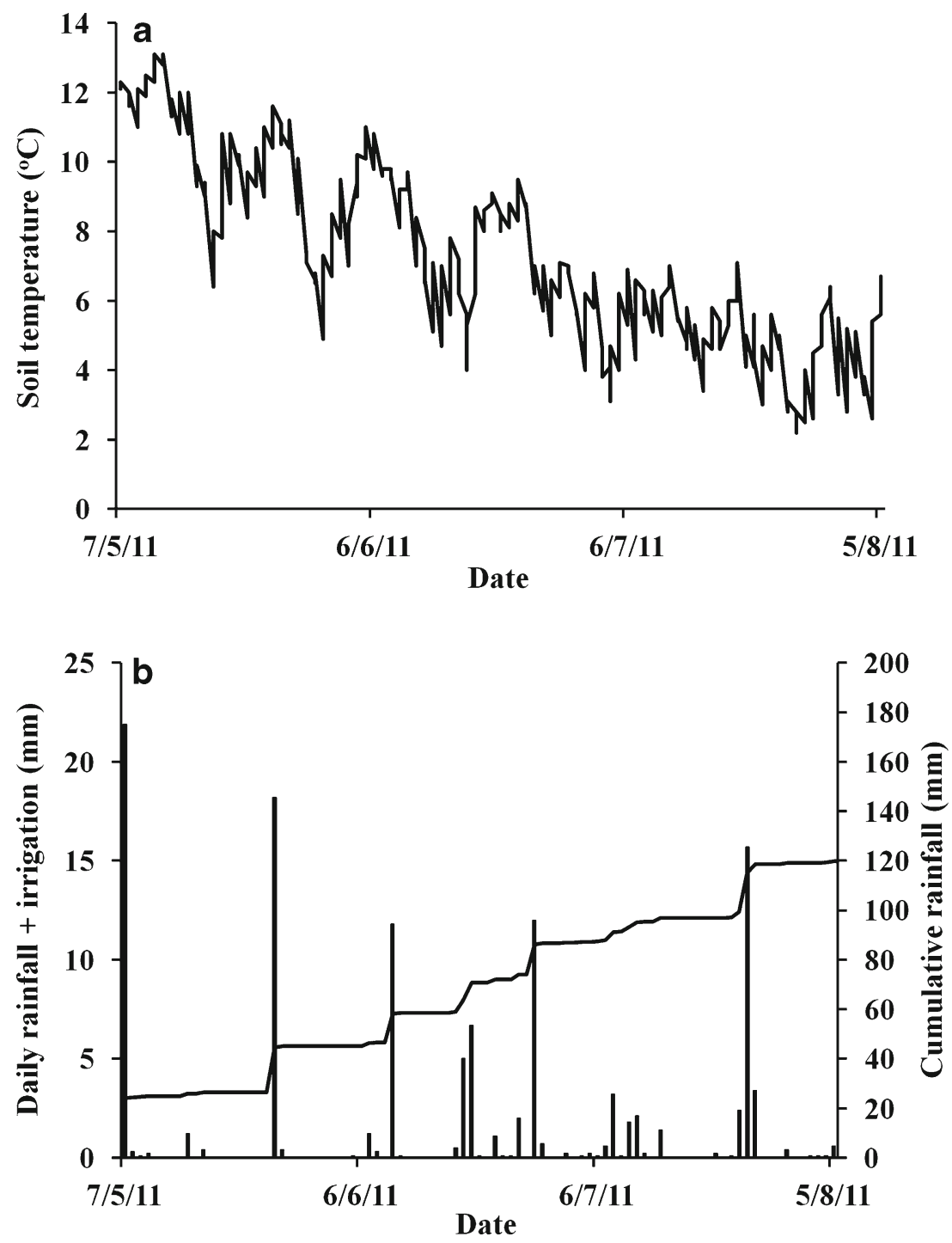

higher than those of control, N50 and N100 treatments at the beginning of the experiment (Fig. 5a, $P<0.05$ ).

For all the treatments without DCD, the soil $\mathrm{NH}_{4}{ }^{+}-\mathrm{N}$ concentration decreased down to near zero levels just after 1 month's application (Fig. 5a). However, the application of DCD maintained the soil $\mathrm{NH}_{4}{ }^{+}-\mathrm{N}$ concentrations above those in the respective non-DCD treatments during most sampling points of the experiment, and this was particularly obvious in the Urine $600+$ DCD treatment (Figs. 5b-d).

Daily $\mathrm{CH}_{4}$ flux and total $\mathrm{CH}_{4}$ uptakes

Daily $\mathrm{CH}_{4}$ flux ranged from $-12.89 \mathrm{~g} \mathrm{CH}_{4} \mathrm{ha}^{-1}$ day ${ }^{-1}$ to $-0.83 \mathrm{~g} \mathrm{CH}_{4}$ ha $^{-1}$ day $^{-1}$. The peak of daily $\mathrm{CH}_{4}$ uptake rates in all treatments occurred on 13th of June (Fig. 6). No significant difference was found in daily $\mathrm{CH}_{4}$ fluxes among the treatments during the experimental period (Fig. 6, $P>0.05$ ).

Total $\mathrm{CH}_{4}$ uptakes varied slightly among treatments, ranging from $0.30 \mathrm{~kg} \mathrm{CH}_{4} \mathrm{ha}^{-1}$ in the control treatment to
$0.44 \mathrm{~kg} \mathrm{CH}_{4} \mathrm{ha}^{-1}$ in the N600+DCD treatment. The total $\mathrm{CH}_{4}$ uptake in the $\mathrm{N} 600+\mathrm{DCD}$ treatment was significantly higher than that of the control treatment (Fig. 7, $P<0.05$ ). However, no significant difference was found in total $\mathrm{CH}_{4}$ uptakes among other treatments (Fig. 7, $P>0.05$ ).

The methanotroph pmo $A$ gene abundance data were used to determine the relationship with the soil $\mathrm{NH}_{4}{ }^{+}-\mathrm{N}$ concentrations. However, no quantitative relationship was found between the soil $\mathrm{NH}_{4}{ }^{+}-\mathrm{N}$ concentrations and methanotroph pmo $A$ gene copy numbers.

\section{Discussion}

Results from this study showed that the methanotroph pmoA gene copy numbers were low in the grazed pasture soil and the application urea-N or animal urine- $\mathrm{N}$ at contrasting rates did not affect the MOB abundance. These results, from a field experiment, support the findings of Di et al. (2011) 

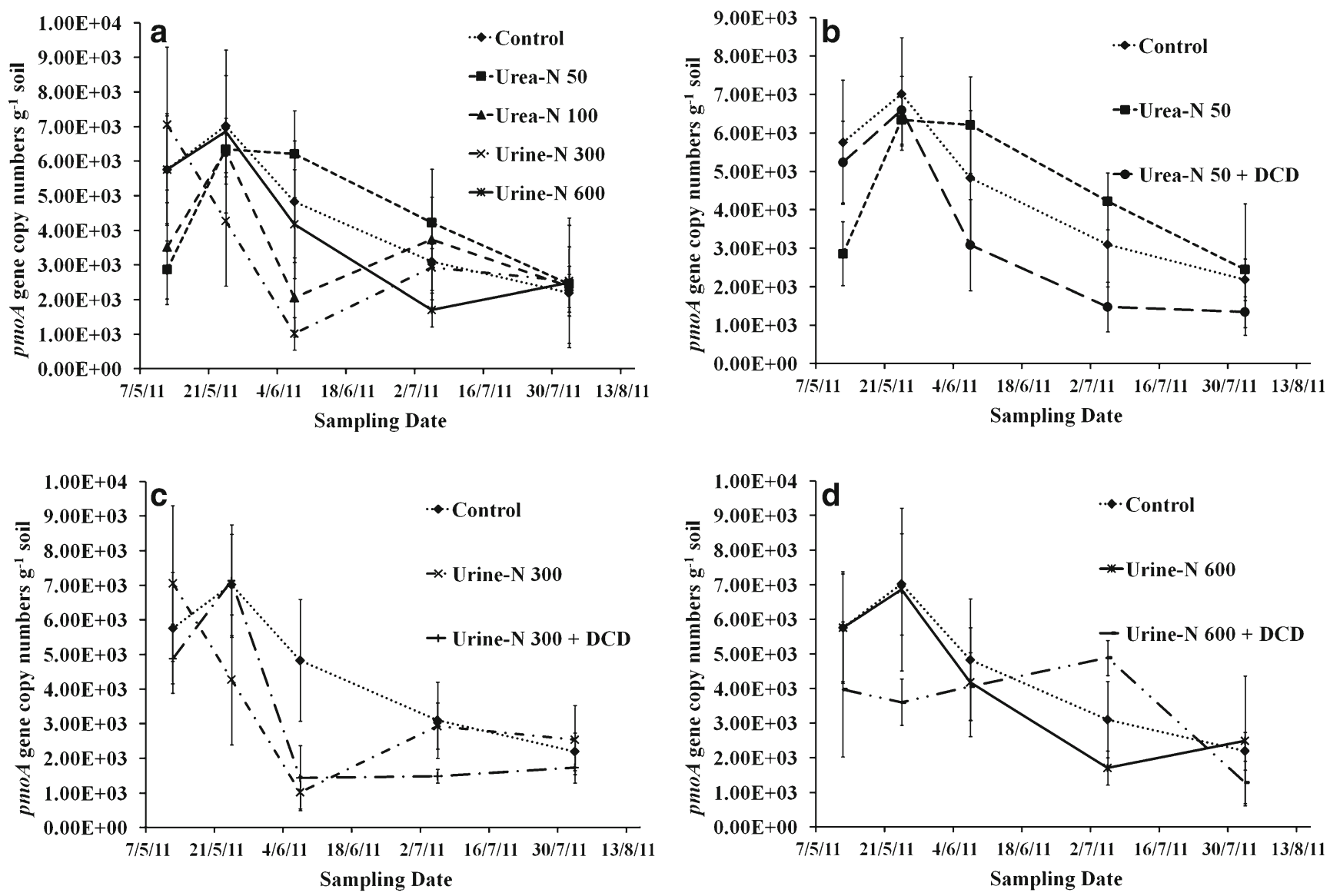

Fig. 2 Methanotroph pmoA gene copy numbers in the soil as affected by the application of different rates of urea and urine and DCD. a All N application treatments. b Urea-N 50 and DCD

treatments. c Urine-N 300 and DCD treatments. d Urine-N 600 and DCD treatments. Vertical bars indicate standard errors of the mean (SEM)

which showed in an incubation study that MOB were not sensitive to the application of animal urine in six grazed

grassland soils and the methanotroph abundance was low in five of the six soils studied. The interactions between $\mathrm{N}$

Fig. 3 The RNA copy numbers of methanotroph $P m o A$ gene in the soil as affected by the application of different rates of urea and urine and DCD at the date of June 7. Vertical bars indicate standard errors of the mean (SEM)

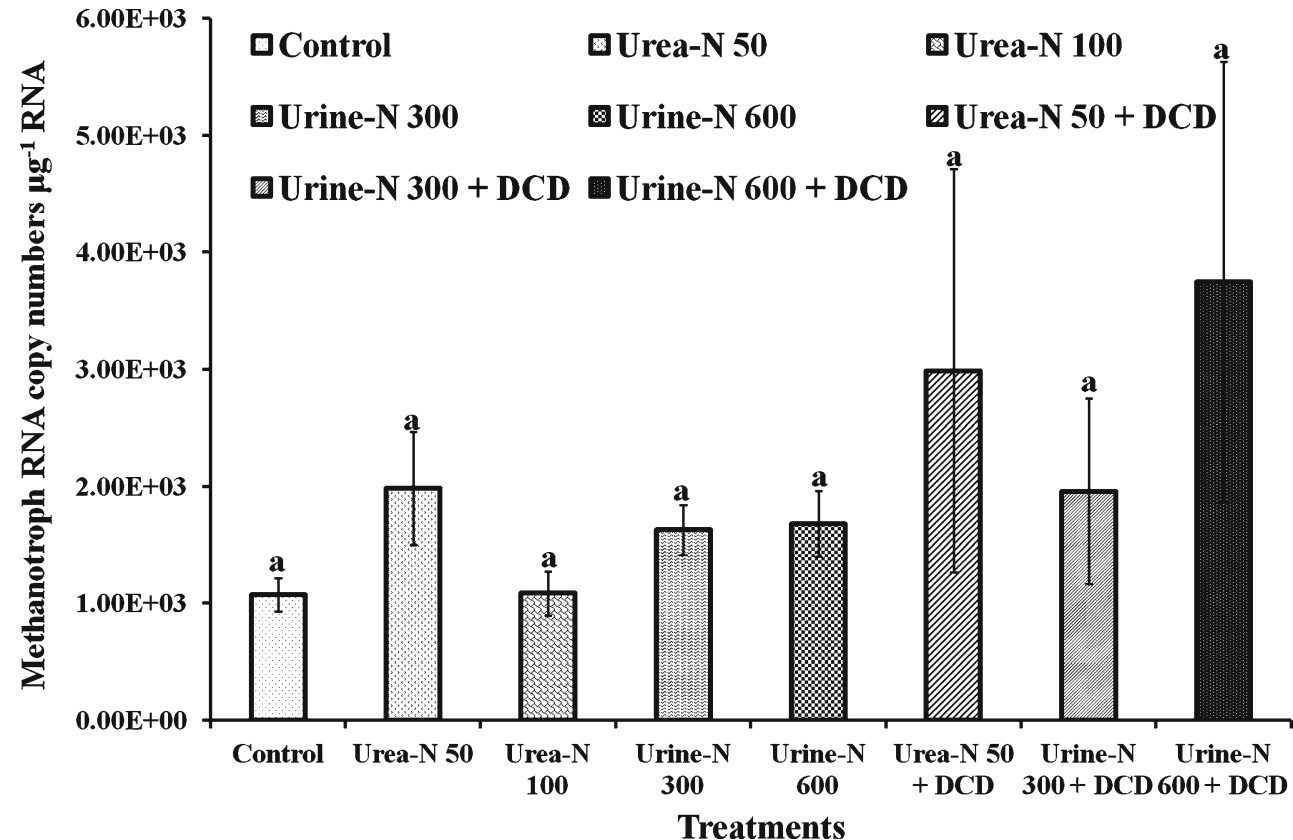


Fig. 4 The relationship between daily average $\mathrm{CH}_{4}$ uptake rates and methanotroph mRNA pmoA gene copy numbers

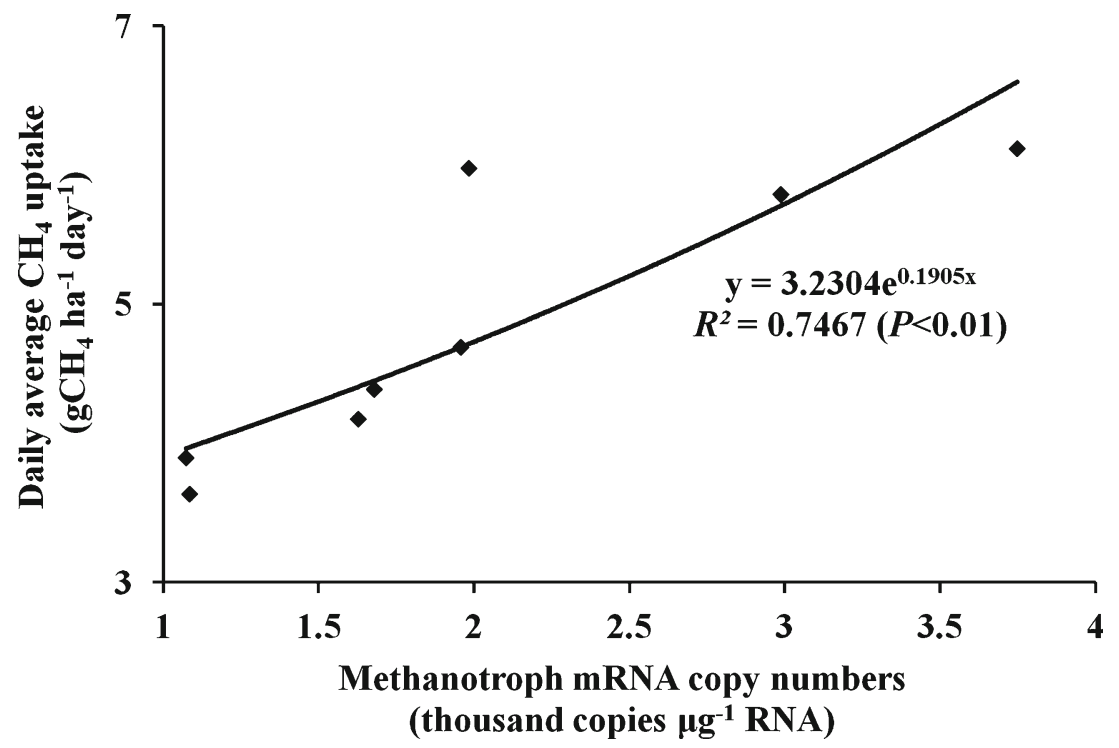

supply and $\mathrm{CH}_{4}$ oxidation are complex and have been reviewed by Bodelier and Laanbroek (2004). Steudler et al. (1989) found that the application of nitrogen fertilizer repressed the $\mathrm{CH}_{4}$ oxidation capacity in forest soils. This would suggest that the consumption of methane can be inhibited by nitrogenous fertilizer additions, probably
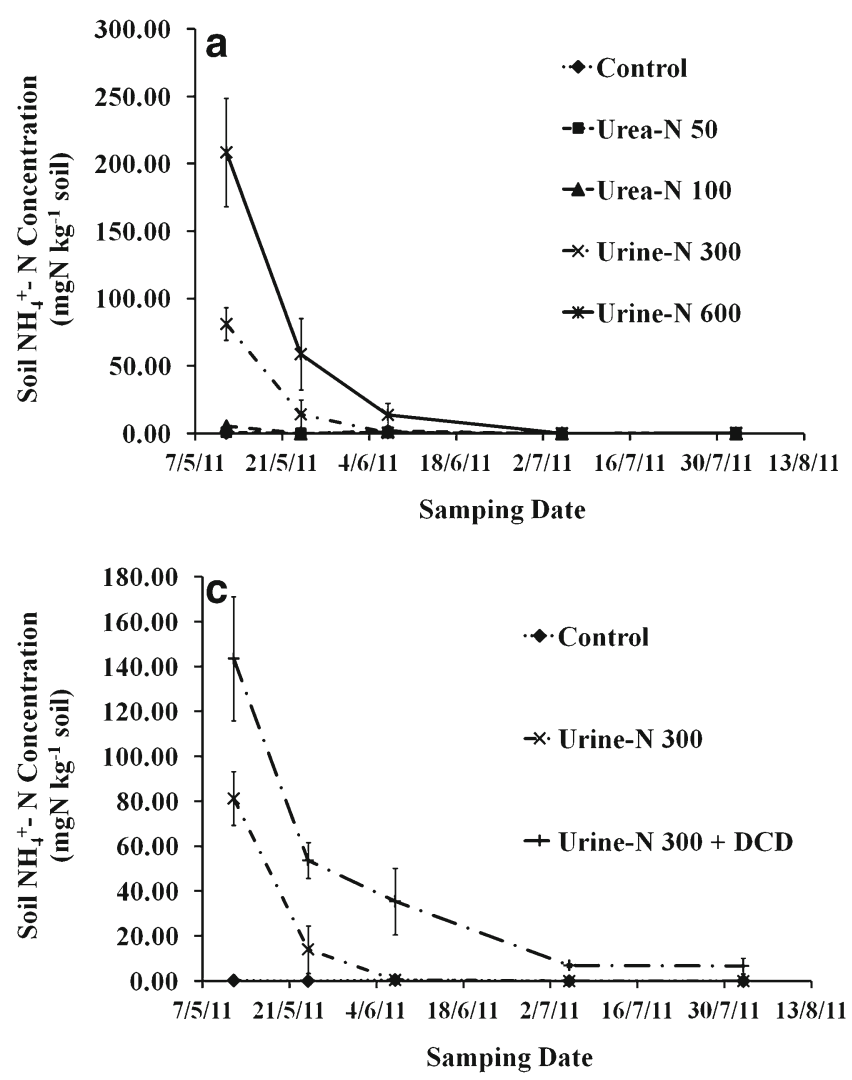

Fig. 5 Ammonium-N concentrations in the soil as affected by the application of different rates of urea and urine and DCD. a All N application treatments. b Urea-N 50 and DCD treatments. c Urine-N 300 and DCD through competitive inhibition of the MMO by ammonia or the toxicity of some intermediate or end products of methanotrophic ammonia oxidation, i.e. hydroxylamine and nitrite (Gulledge and Schimel 1998; Bodelier and Laanbroek 2004; Zheng et al. 2013). However, Bodelier et al. (2000) found that ammonium-based fertilization
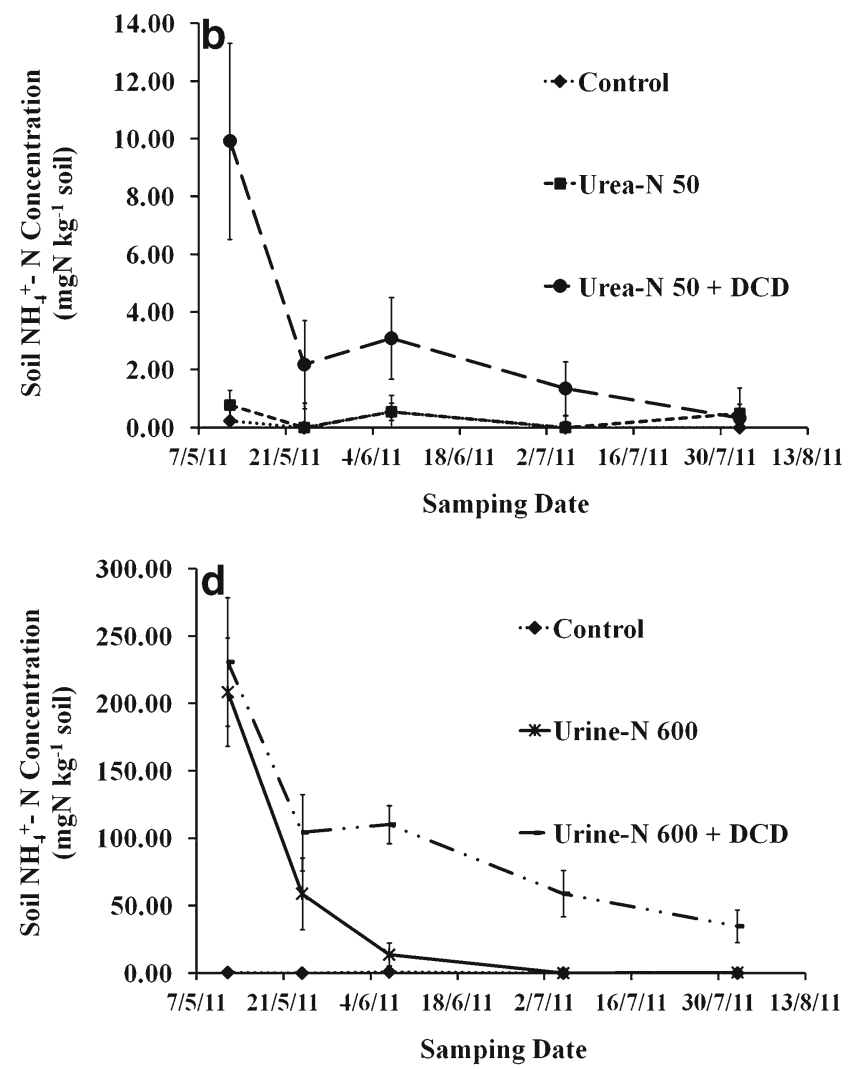

treatments. d Urine-N 600 and DCD treatments. Vertical bars indicate standard errors of the mean (SEM) 

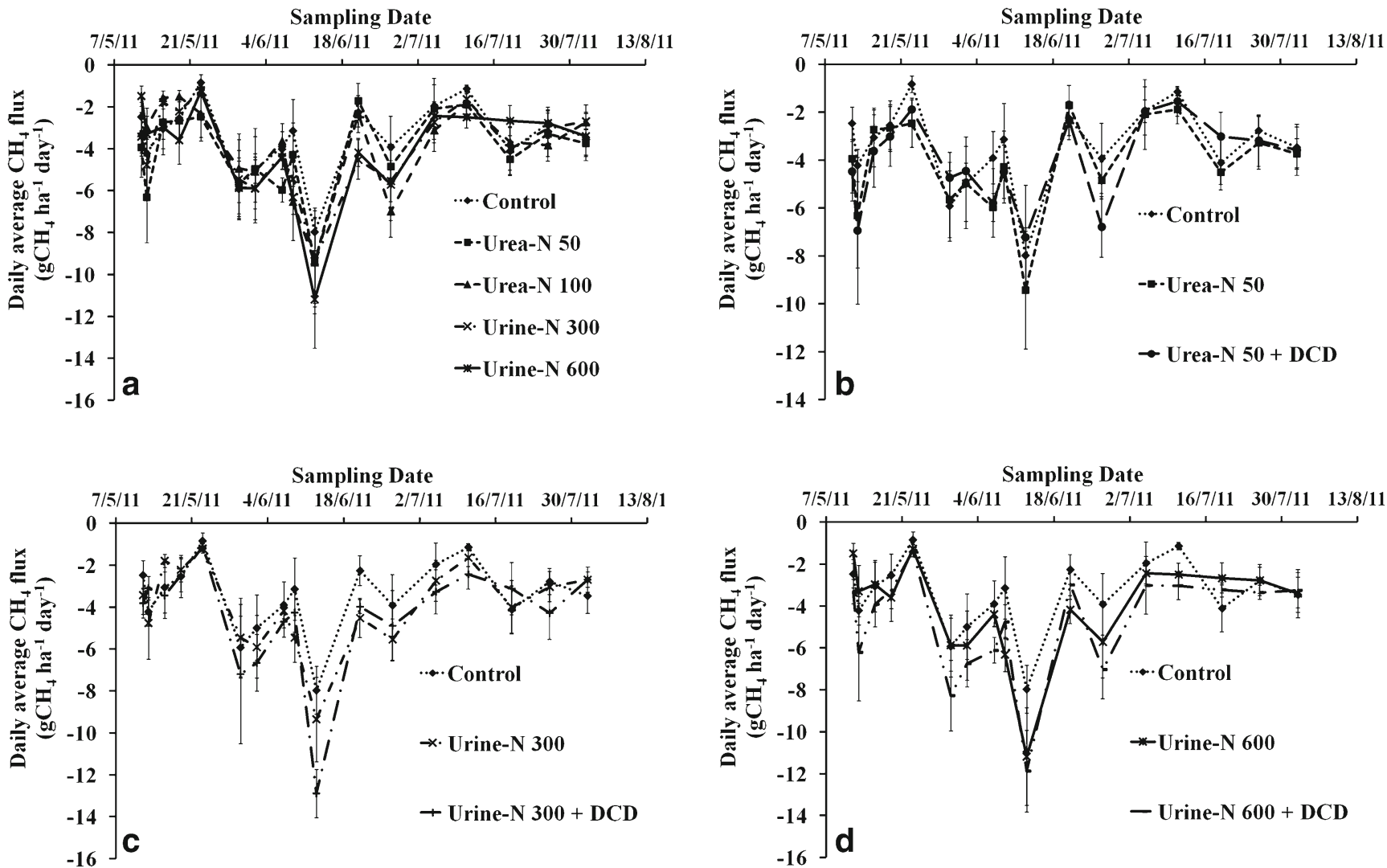

Fig. 6 Daily $\mathrm{CH}_{4}$ flux from the soil as affected by the application of different rates of urea and urine and DCD. a All N application treatments. b Urea-N 50 and DCD treatments. c Urine-N 300 and DCD

treatments. d Urine-N 600 and DCD treatments. Vertical bars indicate standard errors of the mean (SEM)

stimulated growth and activity of methane oxidizers in a rice microcosm. The stimulation was assumed to be induced by the relief of nitrogen limitation for MOB growth by nitrogen fertilizers under N-limiting environments (Bodelier and Laanbroek 2004). Some other studies found no effect on

$\mathrm{CH}_{4}$ oxidation activity by $\mathrm{N}$ fertilizers in soils, possibly due to changes in community composition by a shift between ammonium-tolerant and ammonium-intolerant methaneoxidizing species (Bykova et al. 2007; Shrestha et al. 2010). The low MOB abundance in this study (two or three

Fig. 7 Total $\mathrm{CH}_{4}$ uptakes as affected by the application of different rates of urea and urine and DCD. Vertical bars indicate standard errors of the mean (SEM). Values followed by a common letter are not significantly different at $P=0.05$ using SNK

(Student-Newman-Keuls) test

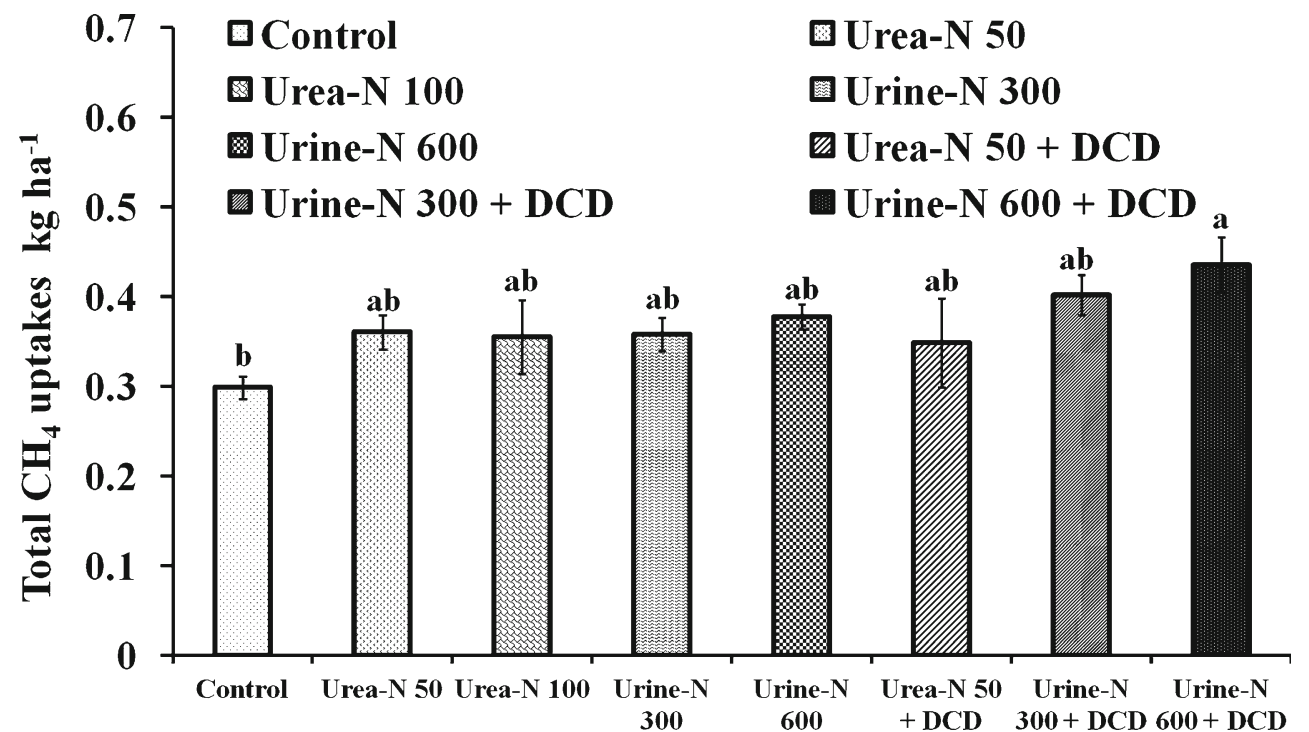

Treatment 
orders of magnitude lower than those reported for other soils; Bykova et al. 2007; Zheng et al. 2008, 2010) could have been caused by the long-term use of $\mathrm{N}$ fertilizers and the high nitrogen loads in the urine patch soil, thus inhibiting MOB growth. In addition, the long-term high nitrogen inputs might have led to an ammonium-tolerant MOB community in the grazed pasture soil which can oxidize $\mathrm{CH}_{4}$ efficiently regardless of $\mathrm{N}$ additions. As a consequence, no significant effect was observed on MOB DNA and mRNA pmoA gene copy numbers with the application of the different urea- $\mathrm{N}$ and animal urine- $\mathrm{N}$ rates, and no quantitative relationship was found between the soil $\mathrm{NH}_{4}{ }^{+}-\mathrm{N}$ concentrations and methanotroph DNA pmoA gene copy numbers in this study.

The daily net $\mathrm{CH}_{4}$ uptakes of this field study were not affected by different nitrogen application rates. This finding agrees with those found in previous field studies (Van den Pol-van Dasselaar et al. 1999; Glatzel and Stahr 2001; Kammann et al. 2001). This result is also in agreement with the lack of a nitrogen effect on the MOB abundance in this grassland soil. About $72 \%$ of the daily $\mathrm{CH}_{4}$ uptakes ranged between $2 \mathrm{~g} \mathrm{CH}_{4} \mathrm{ha}^{-1}$ day ${ }^{-1}$ and $6 \mathrm{~g} \mathrm{CH}_{4}$ $\mathrm{ha}^{-1}$ day ${ }^{-1}$ in this study which was within the range of $\mathrm{CH}_{4}$ uptakes $\left(0-18 \mathrm{~g} \mathrm{CH}_{4} \mathrm{ha}^{-1}\right.$ day $\left.^{-1}\right)$ obtained in previous studies on temperate grassland soils (Mosier et al. 1991; Van den Pol-van Dasselaar et al. 1999; Glatzel and Stahr 2001; Kammann et al. 2001; Shrestha et al. 2012).

The nitrification inhibitor DCD has been developed into an efficient mitigation technology to reduce $\mathrm{NO}_{3}^{-}$leaching and $\mathrm{N}_{2} \mathrm{O}$ emissions from urine patch soils in grazed grassland (Di and Cameron 2005, 2006; Di et al. 2010). In this study, DCD inhibited the nitrification process, thus keeping the soil $\mathrm{NH}_{4}{ }^{+}-\mathrm{N}$ concentration at higher levels than those in the respective treatments without $\mathrm{DCD}$, by deactivating the ammonia monooxygenase enzyme of soil ammonia oxidizers (Amberger 1989). However, DCD did not significantly affect the MOB abundance and daily $\mathrm{CH}_{4}$ uptake rates. This also agrees with results from our previous laboratory incubation study which showed that the application of DCD to the urine patch soils had no significant effect on the MOB abundance in six grassland soils (Di et al. 2011). Delgado and Mosier (1996) found that the soil-atmosphere exchange of $\mathrm{CH}_{4}$ in a barley field was not affected by $\mathrm{N}$ fertilizer or DCD additions over the cropping season. Similarly, Weiske et al. (2001) discovered that in a 3-year field experiment (summer barley 1997-maize 1998-winter wheat 1999), DCD and $\mathrm{N}$ fertilizer did not have a significant effect on $\mathrm{CH}_{4}$ uptakes, whereas the $\mathrm{CH}_{4}$ uptake was slightly stimulated when compared to the control (on average, $1 \%$ higher). Subsequently, Malla et al. (2005) reported that the nitrification inhibitor DCD applied with urea was effective in significantly reducing $\mathrm{CH}_{4}$ emission from rice-wheat cropping systems. Results from this study reinforce the conclusion that the use of the nitrification inhibitor DCD to reduce nitrate leaching and nitrous oxide emissions in grazed grassland soils would not adversely affect the soil's capacity as a $\mathrm{CH}_{4}$ sink. In fact, this study also showed that DCD, when applied with the high rate of animal urine-N $\left(600 \mathrm{~kg} \mathrm{~N} \mathrm{ha}^{-1}\right)$, could potentially benefit the total $\mathrm{CH}_{4}$ uptakes, suggesting that DCD could have a mitigating effect for both $\mathrm{N}_{2} \mathrm{O}$ and $\mathrm{CH}_{4}$ emissions from intensified grazed pasture soils. However, further research is required to verify this finding.

\section{Conclusions}

This field study showed that the MOB population abundance and activity and daily $\mathrm{CH}_{4}$ uptakes were not significantly affected by the application of urea-N or animal urine$\mathrm{N}$ at different rates. Even though DCD was effective at inhibiting ammonium oxidation, it had no effect on the growth of MOB and daily $\mathrm{CH}_{4}$ uptakes. These field experimental results confirm the results of a previous laboratory incubation study (Di et al. 2011) that the MOB abundance is not affected by urine deposition or the application of DCD in grazed pasture soils. This study also showed that DCD applied with animal urine- $\mathrm{N}$ could stimulate $\mathrm{CH}_{4}$ uptakes, thus suggesting the potential of using DCD to mitigate both $\mathrm{N}_{2} \mathrm{O}$ and $\mathrm{CH}_{4}$ in grazed pasture soils.

Acknowledgments We would like to thank the New Zealand Ministry of Primary Industries for providing funding in the form of the LEARN Fellowship to Yu Dai. This study is partially supported by the Natural Science Foundation of China (41020114001) and the Ministry of Science and Technology (2013CB956300). We thank Trevor Hendry, Roger Atkinson, Chris Abraham, Jie Lei, Premaratne Manjula, Steve Moore and Carole Barlow of Lincoln University for technical support.

\section{References}

Amberger A (1989) Research on dicyandiamide as a nitrification inhibitor and future outlook. Commun Soil Sci Plan 20:1933-1955

Bodelier PLE, Laanbroek HJ (2004) Nitrogen as a regulatory factor of methane oxidation in soils and sediments. FEMS Microbiol Ecol 47:265-277

Bodelier PLE, Roslev P, Henckel T, Frenzel P (2000) Stimulation by ammonium-based fertilizers of methane oxidation in soil around rice roots. Nature 403:421-424

Bosse U, Frenzel P, Conrad R (1993) Inhibition of methane oxidation by ammonium in the surface layer of a littoral sediment. FEMS Microbiol Ecol 13:123-134

Bykova S, Boeckx P, Kravchenko I, Galchenko V, Van Cleemput O (2007) Response of $\mathrm{CH}_{4}$ oxidation and methanotrophic diversity to $\mathrm{NH}_{4}{ }^{+}$and $\mathrm{CH}_{4}$ mixing ratios. Biol Fertil Soils 43:341-348

Conrad R (2009) The global methane cycle: recent advances in understanding the microbial processes involved. Environ Microbiol Rep 1:285-292

Costello AM, Lidstrom ME (1999) Molecular characterization of functional and phylogenetic genes from natural populations of 
methanotrophs in lake sediments. Appl Environ Microbiol 65:5066-5074

Dai Y, Di HJ, Cameron KC, He JZ (2012) Effects of nitrogen application rate and a nitrification inhibitor dicyandiamide on ammonia oxidizers and $\mathrm{N}_{2} \mathrm{O}$ emissions in a grazed pasture soil. Sci Total Environ. doi:10.1016/j.scitotenv.2012.08.091

Dedysh SN (2009) Exploring methanotroph diversity in acidic northern wetlands: molecular and cultivation-based studies. Microbiology 78:655-669

Delgado JA, Mosier AR (1996) Mitigation alternatives to decrease nitrous oxides emissions and urea-nitrogen loss and their effect on methane flux. J Environ Qual 25:1105-1111

Di HJ, Cameron KC (2002) Nitrate leaching in temperate agroecosystems: sources, factors and mitigating strategies. Nutr Cycl Agroecosyst 64:237-256

Di HJ, Cameron KC (2005) Reducing environmental impacts of agriculture by using a fine particle suspension nitrification inhibitor to decrease nitrate leaching from grazed pastures. Agric Ecosyst Environ 109:202-212

Di HJ, Cameron KC (2006) Nitrous oxide emissions from two dairy pasture soils as affected by different rates of a fine particle suspension nitrification inhibitor, dicyandiamide. Biol Fertil Soils 42:472-480

Di HJ, Cameron KC, Sherlock RR (2007) Comparison of the effectiveness of a nitrification inhibitor, dicyandiamide, in reducing nitrous oxide emissions in four different soils under different climatic and management conditions. Soil Use Manag 23:1-9

Di HJ, Cameron KC, Shen JP, Winefield CS, O'Callaghan M, Bowatte $\mathrm{S}, \mathrm{He} \mathrm{JZ}$ (2009) Nitrification driven by bacteria and not archaea in nitrogen-rich grassland soils. Nat Geosci 2:621-624

Di HJ, Cameron KC, Sherlock RR, Shen J-P, He J-Z, Winefield CS (2010) Nitrous oxide emissions from grazed grassland as affected by a nitrification inhibitor, dicyandiamide, and relationships with ammonia-oxidizing bacteria and archaea. J Soil Sediment 10:943-954

Di HJ, Cameron KC, Shen JP, Winefield CS, O'Callaghan M, Bowatte S, He JZ (2011) Methanotroph abundance not affected by applications of animal urine and a nitrification inhibitor, dicyandiamide, in six grazed grassland soils. J Soil Sediment 11:432-439

Glatzel S, Stahr K (2001) Methane and nitrous oxide exchange in differently fertilised grassland in southern Germany. Plant Soil 231:21-35

Gulledge J, Schimel JP (1998) Low-concentration kinetics of atmospheric $\mathrm{CH}_{4}$ oxidation in soil and mechanism of $\mathrm{NH}_{4}^{+}$inhibition. Appl Environ Microbiol 64:4291-4298

Hanson RS, Hanson TE (1996) Methanotrophic bacteria. Microbiol Rev 60:439-471

He JZ, Hu HW, Zhang LM (2012) Current insights into the autotrophic thaumarchaeal ammonia oxidation in acidic soils. Soil Biol Biochem 55:146-154

Hewitt AE, Whenua M (1998) New Zealand soil classification. Manaaki Whenua Press, Lincoln

Holmes AJ, Costello A, Lidstrom ME, Murrell JC (1995) Evidence that participate methane monooxygenase and ammonia monooxygenase may be evolutionarily related. FEMS Microbiol Lett 132:203-208

Hutchinson GL, Mosier AR (1981) Improved soil cover method for field measurement of nitrous oxide fluxes. Soil Sci Soc Am J 45:311-316

IPCC (2007) Climate change 2007: the physical science basis. Contribution of Working Groups I to the Fourth Assessment Report of the Intergovernmental Panel on Climate Change. IPCC Secretariat, Geneva

Kammann C, Grünhage L, Jäger HJ, Wachinger G (2001) Methane fluxes from differentially managed grassland study plots: the important role of $\mathrm{CH}_{4}$ oxidation in grassland with a high potential for $\mathrm{CH}_{4}$ production. Environ Pollut 115:261-273

Kolb S (2009) The quest for atmospheric methane oxidizers in forest soils. Environ Microbiol Rep 1:336-346

Kolb S, Knief C, Stubner S, Conrad R (2003) Quantitative detection of methanotrophs in soil by novel pmoA-targeted real-time PCR assays. Appl Environ Microbiol 69:2423-2429

Krüger M, Frenzel P (2003) Effects of $\mathrm{N}$-fertilisation on $\mathrm{CH}_{4}$ oxidation and production, and consequences for $\mathrm{CH}_{4}$ emissions from microcosms and rice fields. Global Change Biol 9:773-784

Külling DR, Dohme F, Menzi H, Sutter F, Lischer P, Kreuzer M (2002) Methane emissions of differently fed dairy cows and corresponding methane and nitrogen emissions from their manure during storage. Environ Monit Assess 79:129-150

Malla G, Bhatia A, Pathak H, Prasad S, Jain N, Singh J (2005) Mitigating nitrous oxide and methane emissions from soil in rice-wheat system of the Indo-Gangetic plain with nitrification and urease inhibitors. Chemosphere 58:141-147

Mosier A, Schimel D, Valentine D, Bronson K, Parton W (1991) Methane and nitrous oxide fluxes in native, fertilized and cultivated grasslands. Nature 350:330-332

Shen XY, Zhang LM, Shen JP, Li LH, Yuan CL, He JZ (2011) Nitrogen loading levels affect abundance and composition of soil ammonia oxidizing prokaryotes in semiarid temperate grassland. J Soil Sediment 11:1243-1252

Shrestha M, Shrestha PM, Frenzel P, Conrad R (2010) Effect of nitrogen fertilization on methane oxidation, abundance, community structure, and gene expression of methanotrophs in the rice rhizosphere. ISME J 4:1545-1556

Shrestha PM, Kammann C, Lenhart K, Dam B, Liesack W (2012) Linking activity, composition and seasonal dynamics of atmospheric methane oxidizers in a meadow soil. ISME J 6:1115-1126

Staff SS (1998) Keys to soil taxonomy. United States Department of Agriculture, US Government Print office, Washington, DC

Steudler PA, Bowden RD, Melillo JM, Aber JD (1989) Influence of nitrogen fertilization on methane uptake in temperate forest soils. Nature 341:314-316

Van den Pol-van Dasselaar A, Van Beusichem ML, Oenema O (1999) Effects of nitrogen input and grazing on methane fluxes of extensively and intensively managed grasslands in the Netherlands. Biol Fertil Soils 29:24-30

Vorobev AV, Baani M, Doronina NV, Brady AL, Liesack W, Dunfield PF, Dedysh SN (2011) Methyloferula stellata gen. nov., sp. nov., an acidophilic, obligately methanotrophic bacterium that possesses only a soluble methane monooxygenase. Int J Syst Evol Microbiol 61:2456-2463

Weiske A, Benckiser G, Herbert T, Ottow J (2001) Influence of the nitrification inhibitor 3, 4-dimethylpyrazole phosphate (DMPP) in comparison to dicyandiamide (DCD) on nitrous oxide emissions, carbon dioxide fluxes and methane oxidation during 3 years of repeated application in field experiments. Biol Fertil Soils 34:109-117

Zhang LM, Hu HW, Shen JP, He JZ (2012) Ammonia-oxidizing archaea have more important role than ammonia-oxidizing bacteria in ammonia oxidation of strongly acidic soils. ISME J 6:1032-1045

Zheng Y, Zhang LM, Zheng YM, Di H, He JZ (2008) Abundance and community composition of methanotrophs in a Chinese paddy soil under long-term fertilization practices. J Soil Sediment 8:406-414

Zheng Y, Liu XZ, Zhang LM, Zhou ZF, He JZ (2010) Do land utilization patterns affect methanotrophic communities in a Chinese upland red soil? J Environ Sci 22:1936-1943

Zheng Y, Zhang LM, He JZ (2013) Immediate effects of nitrogen, phosphorus and potassium amendments on the methanotrophic activity and abundance in a Chinese paddy soil under short-term incubation experiment. J Soil Sediment 13:189-196 